УДК 339.92:332.1

\title{
Sergei KOVALENKO
}

PhD in Economics, Associate Professor, Department of humanitarian sciences, Danube Institute of «Odessa Maritime Academy» National University, e-mail: econ69@mail.ru

\section{PROSPECTS OF LEADERSHIP FOR UKRAINIAN ECONOMY IN THE BLACK SEA EUROPEAN REGION}

Kovalenko, S. (2015), Prospects of leadership for Ukrainian economy in the Black Sea European region [Perspektyvy liderstva ekonomiky Ukrainu v Chornomorskomu Yevrorehioni; za red.: M. I. Zveriakova (gol. red.) ta in.], Socio-economic research bulletin; Visnik social'no-ekonomičnih doslidžen' (ISSN 2313-4569), Odessa National Economic University, Odessa, No. 2 (61), pp. 40-49.

\begin{abstract}
The article researches one of possible vectors of Ukrainian integration in view of modern geo-economical transformations taking into consideration the most actual trends in development of worldwide economy and international relations. Integration processes within the framework of Black Sea Economic Cooperation Organization (BSECO) are reviewed as an aid to adapt national economy of Ukraine to modern geo-economical transformation in worldwide economy. Involvement and participation of Ukraine in regional structure of the Black Sea Economic Cooperation is caused by transit nature of its economy. Cooperation within the BSECO is one of the most important directions contributing into economic and energetic stability of Ukraine encompassing such projects, as seaports improvement and reconstruction, cyclic Black Sea road and gas pipelines running across the Black Sea. The Black Sea electric power ring is vitally important for both Ukrainian and European stability.
\end{abstract}

Keywords: Ukraine; integration; globalization; regionalization; geo-economical transformation; Black Sea European Region; cross-border cooperation.

\section{Сергій Іванович КОВАЛЕНКО}

кандидат економічних наук, доцент кафедри гуманітарних дисичиллін, Національний університет «Одеська морська академія», Дунайський інститут, е-таil: econ69@таil.ru

\section{ПЕРСПЕКТИВИ ЛІДЕРСТВА ЕКОНОМІКИ УКРАЇНИ В ЧОРНОМОРСЬКОМУ СВРОРЕГІОНІ}

Коваленко, С. І. Перспективи лідерства економіки Украӥни в Чорноморському єврорегіоні / Сергій Іванович Коваленко // Вісник сочіально-економічних досліджень: зб. наук. праџь (ISSN 2313-4569). - Одеса: Одеський національний економічний університет. - 2016. - № 2 (61). - C. 40-49.

\begin{abstract}
Анотація. У статті досліджено один із можливих векторів інтеграції України в умовах сучасних геоекономічних трансформацій з урахуванням найбільш актуальних тенденцій розвитку світової економіки $i$ міжнародних відносин. Інтеграційні прочеси в рамках Організації Чорноморського Економічного Співробітництва (ОЧЕС) розглядаються як засіб адаптаџії національного господарства Украӥни до сучасних геоекономічних трансформацій світової економіки. Участь України в регіональному об'єднанні Чорноморського економічного співробітництва обумовлена транзитивним характером ії економіки. Одним із найбільш важливих напрямків забезпечення економічної та енергетичної стабільності України є співпраця в рамках ОЧЕС. Удосконалення та реконструкція морських портів, кільцева чорноморська автострада $i$ трансчорноморські газопроводи, Чорноморське електроенергетичне кільце життєво необхідні для української та європейської стабільності.
\end{abstract}

Ключові слова: Украӥна; інтеграція; глобалізація; регіоналізація; геоекономічні трансформації; Чорноморський єврорегіон; транскордонне співробітництво.

\section{Сергей Иванович КОВАЛЕНКО}

кандидат экономических наук, дочент кафедры гуманитарных дисииплин, Наџиональный университет «Одесская морская академия», Дунайский институт, e-mail: econ69@mail.ru 


\title{
ПЕРСПЕКТИВЫ ЛИДЕРСТВА ЭКОНОМИКИ УКРАИНЫ В ЧЕРНОМОРСКОМ ЕВРОРЕГИОНЕ
}

Коваленко, С. И. Перспективы лидерства экономики Украины в Черноморском еврорегионе / Сергей Иванович Коваленко // Вестник сочиально-экономических исследований: сб. науч. трудов (ISSN 2313-4569). - Одесса: Одесский национальный экономический университет. - 2016. - № 2 (61). - C. 40-49.

\begin{abstract}
Аннотация. В статье исследован один из возможных векторов интеграции Украины в условиях современных геоэкономических трансформаций с учётом наиболее актуальних тенденций развития мировой экономики и международных отношений. Интегращионные прочессы в рамках Организации Черноморского Экономического Сотрудничества (ОЧЭС) рассматриваются в качестве способа адаптачии национального хозяйства Украинь к современным геоэкономическим трансформациям мировой экономики. Участие Украины в региональном объединении Черноморского экономического сотрудничества обусловлено транзитивным характером ее экономики. Одним из важнейтих направлений для обеспечения экономической и энергетической стабильности Украины является сотрудничество в рамках ОЧЭС. Усовершенствование и реконструкция морских портов, кольиевая черноморская автострада и трансчерноморские газопроводы, Черноморское электроэнергетическое кольио жизненно необходимы для украинской и европейской стабильности.
\end{abstract}

Ключевые слова: Украина; интеграция; глобализация; регионализация; геоэкономические трансформации; Черноморский еврорегион; трансграничное сотрудничество.

JEL classification: C120; C140; C180

\section{Introduction}

Activation of integration processes in Eastern Europe demands changes in researches direction vector towards problems of trans-border cooperation and its newer forms development prospects in the context of post-industrial paradigm. Trans-border cluster incorporations become new format of inter-regional development. Individual corporations don't compete at a market; competition is between entire complexes, which reduce their expenditures due to joint technological cooperation. It is therefore that the implementation of investments and innovations projects within trans-border clusters should strengthen competition with corporations operating autonomously and attract foreign investors. Nowadays, application of European experience in trans-border cluster cooperation within the EU is considered as one of the most efficient ways of development of territories of States adjacent to borders. Theoretical basis of a cluster is studied deeply enough in worldwide economic science. Yet, processes of globalization and regionalization and international economic competition and cooperation associated with them make studying specific features of trans-border clusters more actual with purposes to use their potential to improve competitiveness of States involved into integration formations [1, p. 351].

Success of steady development of national economy gets more and more dependent on geoeconomic factors [2]. Nowadays world witnesses global geo-economic transformations which display themselves, first of all, in processes of economization in policy and in emergence of newer power centers. Geo-economical analysis becomes an essential component of cornerstone basis of international economic relations both in global and in regional aspects. In this view particular significance shifts towards problem of determination of integration priorities of Ukraine taking into account national aims and interests [3, p. 10].

\section{Analysis of latest researches and publications}

Michael Porter in his work "The Competitive Advantage of Nations" comes to the conclusion that when the investment policies are being worked out emerging economies must aim at the development of interrelating industrial clusters on the ground of primary and secondary spheres. The approach to the evaluation of competitiveness of the region can be defined with the help of the concept of competitive advantage of the country, offered by M. Porter. 
The relevant topic is widely reflected in the works of many Ukrainian scientists: V. Hayets' [5], N. Mikula [6], M. Dolyshni [7], Yu. Makohon [9], S. Maksymenko, P. Bielenki, etc. Their scientific research results are connected with the study of spatial development and cooperation of the boundary regions in terms of the EU functioning, applying the corresponding experience for Ukraine. At present there exist various hybrid forms of cross-border quasiintegration such as clusters, business associations, strategic alliances, various network-societies, etc. They are the associations of the European regions economic entity with steady long-term relations between them and delegation of control on management of the general operations without any legally-issued transfer of the right to property [4, p.17]. This problems is being under study with a number of national and foreign researchers, such as B. Parakhonsky, A. Neklessa, S. Tsymburskiy, S. Dergachev, P. Kiryakov and others, who rather scrupulously revealed subjects relevant to geoeconomical transformations of modern worldwide economy in general in their works. However, matters relevant to positioning Ukraine as a party in regional geo-economical relations are not revealed completely [5, p. 244].

\section{Problem description}

Aim of the work being presented consists in exploring of one of probable vectors of integration of Ukraine in view of modern geo-economical transformation taking into consideration the most actual trends in development of worldwide economy and international relations. The proposed work consists in exploring approaches to structuring a development potential of trans-border cluster systems - poles of competitiveness - as an object of strategy planning in conditions of demand to develop a strategy for European regional development on the basis of innovative forms potential evaluation for industrial integration of peripheral economic area entities [6, p.129].

Worldwide economic system at the beginning of the $3^{\text {rd }}$ millennium features activation of processes of development of newer mutually acceptable development schemes, which take into note geoeconomical balance of forces established within the world. For the last years the role played by great economic powers and correlations of their political and particularly economic possibilities changed notably. New powers appeared reasonably claiming for their place among the world leaders, such as India and China with their economy achieving substantial progress. At the same time it is possible to state that modern conditions make it a very complicated matter for an individual State, whatever her level of development could be, to adopt all the decisions in respect of achieving national interests by itself without support of neighboring States. It causes to delegate a part of national sovereignty to super-national formations which provides for cooperative model to solve problems of development on a regional level and, as a consequence, worldwide in total [7, p.11].

Importance of European regional aspect of strategic planning; integration of the most actual problems of development of trans-border regions with actions of authorities in peripheral economic area to solve such problems; evaluation of consequences of their existing and reproduction; insistent demand for methodology of strategic planning at European regional level requires, as a priority, to consider specific features of European regional Target Implementation Systems (TIS). Process of social and economic development in peripheral regions often experiences situations with changes in external and internal conditions increase beyond subjective adaptive capabilities, i.e. lack of levers to eliminate a problem occurs with governing bodies. In this work a trans-border cluster system is considered as a problem-solving system being a result of external addition to problematic TIC by parties being competent to control factors contributing to the problems' reproduction [8, p. 456].

\section{The Essential Research Material}

Geo-economic interests of Ukraine may be formulated, as follows: providing steady economic progress and competitiveness of national economy; creation of favorable conditions for successful upgrade of national economy; maintenance and improvement of scientific and technological potential; implementation of development model based on innovations; integration of Ukraine into 
European political, economic, legal environment and into Euro-Atlantic safety environment; development of equal-rights, mutually beneficial relations of Ukraine with other States worldwide.

Cooperation within the framework of regional integrating structures is essentially important for Ukraine in the aspect of strengthening national economy and realizing geo-economic interests both on regional and global levels.

To our opinion "...Ukraine has a chance to obtain status of affluent regional power or regional leader, provided it makes important political steps and implements large-scale trans-national economic projects, i.e. internationalization of Ukrainian economy. Basing on political and economical demands, Ukraine should strive to create a multilateral regional system of international cooperation.” [9, p. 36]. A number of other national scientists share the stated opinion. "In a sub-regional dimension (within the closest surrounding) Ukraine keeps a status of a great regional power with substantial potential giving it a chance to promulgate active policy to implement its own interests. As an inheritor of a certain part of interests, aims and problems of the former USSR in Central and South-Eastern Europe, in the Black Sea Region Ukraine should play a significant part in new order system establishment. It is essentially important for Ukraine to settle conflict situations in the Balkans, Trans-Dniester Region, the Caucasian Region, forming equal partnership models with Poland, Turkey, Russian Federation as powerful regional leaders within appropriate parts of the world."

The Black Sea vector of integration represents a particular interest from the point of view of its economic potential. Importance and peculiarity of the Black Sea Region lies, first of all, in its being shared between three civilizations - western, eastern orthodox and Islamic. The Black Sea basin was historically a place of coexistence and transfusion, though not always peaceful and friendly, for various cultures, religions and economic models. Nowadays the importance of this region increased further due to active Caspian Sea oil fields development. Experts from National Institute of International Safety Problems keep to an opinion that "geopolitical situation within the region is to larger extent determined by role of national interests of a number of regional and other concerned States than by human rights protection, anti-terrorism struggle or religious extremism. In a broader context, the matter is in gaining strategic advantages by main political actors - the USA and the RF... Complex of economic problems of regional development may be considered as a factor of unequal influence potential distribution between the USA and the RF. It creates favorable conditions and is an aid to turn a majority of States of the region in question to a wider dialogue with the USA and Western powers... The region is extremely important for Ukraine in geopolitical aspect both from the point of view of its economical interests (solution of an energy resources problem, increasing foreign trade volumes, smooth transport operation), and from the point of view of national security of the State.".

The key directions of regional policy of Ukraine in the Black Sea Region are, as follows:

- developing partnership relations with the EU and search for new possibilities for European integration by means of active involvement into the EU political activities in the Black Sea Region and facilitation to the EU political efforts in Asia;

- implementation of European and regional economical projects, particularly in the sphere of logistics and transport;

- implementation of European and regional economical projects in the sphere of energy, directed towards energy safety of Ukraine, its regional partners and the EU in general;

- especially particular significance for Ukraine has diversification of sources of supply of energy resources and formation of newer transit routes via Ukrainian territory;

- strengthening part played by Ukraine by means of increasing cooperation in policy, security and economy spheres within the framework of the GUAM, BSECO and other regional organizations.

In view of implementation of this policy, cooperation between Ukraine and neighboring States within the scope of the Black Sea Economic Cooperation Organization (BSECO), established in 1992, at ht initiative of Turkey, is seen as the most prospective. Analyzing list of participants it is reasonable to state that the BSECO draws together states with various social and economic forms of national state organization basing on common European integration of its members. At present, 
constant BSECO members are Azerbaijan, Albania, Armenia, Bulgaria, Greece, Georgia, Moldova, Russian Federation, Romania, Serbia, Turkey, Ukraine. 13 states possess the observer status and include Austria, Belarus, Germany, Egypt, Israel, Italy, Poland, Slovakia, the USA, Croatia, Tunis, France, Чехия. The Organization declares as its aim to promote economical development and stability in the Black Sea Basin. Among major items of its activities one may highlight, as follows: assistance in transport and various types of communications development; assistance in steady economical development of member States by means of creation of favorable climate for business activities and free trading system formation in the region; solving problems of energetic safety in the region; tourism; science and technology. Further difference of the BSECO from other integration grouping consists in the fact that it does not aim to create any political or military alliances. Cooperation lies only in economical and scientific areas.

Fruitful cooperation between Ukraine and the BSECO partners is extremely important in geoeconomical aspect. Activation of political and economic participation of Ukraine in this organization might contribute to strengthening of significance of our State in the world. Ukraine possesses sufficient economical, scientific and political potential to occupy a significant place in geo-economical formations within the Black Sea Region. Economical advantages from expanding cooperation are also impressive. In addition to mutually benefit trade and development of business opportunities rise to implement large scale economical projects. One should bear in mind, that transport communications of European level run through the Black Sea Region.

Skilful application of the above factors to national interest may bring substantial benefits. Furthermore, it is extremely important for national economy to provide both newer markets for own productions and services and to divert sources of energy producing resources supply.

Modern transformations in geo-economical paradigm of worldwide economy demand from national economies quick reaction and prompt adaptation to newer challenges. Domination of economical interests over military and, sometimes, political may be noted among the brightest examples of modern transformations. Another objective tendency in worldwide economical development consists in distribution of spheres of influence between leading states or their groupings. It is connected with active economical development of a number of states in Asia and Latin America, such as India, China, Brazil which now tend to play not only independent, but eventually decisive part in the worldwide economy.

More influence is being gained by various integrating groupings which place as their main objective stable social and economical development of their member states.

Under such circumstances it is very important for Ukraine to determine correct integrating directions which may provide a due place for national economy in worldwide economical system. From this point of view the Black Sea vector of international cooperation is particularly interesting. Its features a unique economical and geographical position as located on crossways of commercial routes linking North and South, West and East. With undisputable advantages in transit goods and services it, however, features certain obstructions for successful integration processes. There are more than 10 states in the region, counting not only directly possessing parts of the Black Sea coast, but also situated nearby and having certain economical interests in the region. Majority of these states belongs to different civilization with different models and stereotypes of their development, complicated history of mutual relations with adjacent neighbors, territorial claims to each other. All these factors affect processes of integration negatively, prevent prompt approval of important economical solutions.

The BSECO represents a positive integration tendency. Ukrainian participation in the BSECO is predestinated by transit nature of Ukrainian economy and need for integration into worldwide economic environment on decent terms. Implementation of great transport project within the BSECO framework is of great significance for national economy. The first place is occupied by building of pipeline system for oil and gas transit to Europe. Possibility of diverting energy producing resources supply sources to meet needs of national economy is also of great significance 
as well as expansion of sale market for own manufactured goods. Furthermore, fruitful cooperation with the BSECO construes one more step towards European integration of Ukraine, since the BSECO members include three EU member states and four NATO member states. Thus, successful implementation of the Black Sea integration vector enables Ukraine to use advantages brought by globalization to the top extent and to occupy a decent place in the modern worldwide economical system. Regional specific features and its members orientation towards economical transformation and integration places a number of problems influencing both further activity of the organization and even its very existence. Majority of states in the region have rather obsolete, weak organization and actually unprotected information environment which substantially increases potential communication expenditures in the course of BSECO activities.

However, despite problems substantially retarding processes of integration in the Black Sea Region, cooperation both on bilateral and multi-lateral basis continues to develop due to interest of all the parties involved into regional relations within the Black Sea Region to increase efficiency of integration interactions at certain directions, among which following aspects should be particularly noted:

1. Creating a mode of free transfer of goods, services and finances to stimulate economical contacts and expand the framework of cooperation in manufacturing and investments;

2. Formation of bank infrastructure and a network of business centers to provide funding and information support both governmental and private investments into projects dealing with infrastructure.

3. Unifying the customs system in the regional states to create an efficient system of multilateral payments with further development into the Black Sea Payments Union.

4. Support of cooperation of the Black Sea states in privatization processes, minor and medium business sphere, efficient complex usage and protection of biological, mineral and aquatic resources of the Black Sea.

5. Forming a transport infrastructure by means of establishing newer and upgrade of existing transport communication and expanding railway and air communications between the BSECO member States.

6. Development of modern telecommunications system to provide reliable telephone communications between the Black Sea states, particularly in the framework of project of unified fiber-optical communication line in Italy, Turkey, Bulgaria, Romania and Ukraine and connecting to Euro-Asian cable linking Europe with Korea and Japan.

7. Establishing European transport corridor and cooperation in oil extraction and oil transfer to Central and Eastern Europe.

Among other key directions, which lately became actual and insistent, the most notable is a process of cooperation in development of fuel and power basis so as to use energy efficiently, to provide joint funding for power producing plants, to reconstruct oil and gas transfer pipelines, built terminals and storage facilities of oil and liquefied gas, to put into action newer and reconstruct existing coal mines, to implement mining equipment of newer generation, and to apply nontraditional energy sources. Taking into note that all the BSECO member states strive to play notable part in the Black Sea Region, including safety aspects, they find it feasible to convert their military industry to mass production of competitive goods of high quality [9, p. 28].

It should be noted that success or failure of regional cooperation of the Black Sea states greatly depends on, firstly, efficient solving problems of economical and political nature and readiness of participating states to full-scale cooperation taking into due account interests of other partners and on what state will become a leader in BSECO. Secondly, efficiency of integration in the Black Sea Region also depends from capability of participants to adapt social aspect of development. Substantial difference in social standards together with existing discrepancies in motivation of economical behavior construes objectively one of the essential factors weakening the intensity of integration processes and, as a result, increasing transaction expenditures of international economical integration, especially communications costs. 
It may be stated, as a main conclusion, that primary solution to provide efficient cooperation within the BSECO lies in settling political problems which don't bear a principal nature for any of the states, but, accumulating, worsen substantially general political situation. At the same time, certain matters with radical difference in approach by involved states should be assigned a total moratorium for discussion and status-quo should be kept. At the first turn, this provision should be applied to borders' demarcation. Finally, real cooperation in humanitarian and cultural areas should be achieved, information space should be mutually opened, since its being the only way to mutual understanding on the basis of convergence and changes in formal and informal institutions. It will make a positive influence upon the level of transactions expenditures of international economical integration with further BSECO functioning.

Economical processes associated with the Black Sea Region lately gained their advance, in particular within the energy branch. Russian Federation, as the greatest power in the region, shows particular activeness in the sphere of new ideas generation and their implementation into consistent plans of multilateral mutually benefit project within the entire period of expanded Black Sea zone, especially in extraction and supply of energy producing resources to consumer market. Two project available in actual agenda - the Black Sea transport ring and the Black Sea electric power supply ring - are initiated by Russia and are supported at the top level.

Project of power supply systems synchronization between states of Western, Central and Southern Europe with those of the CIS and Baltic states is also important. Once implemented, it should be able to assist in creation of the Black Sea power ring involving all the European states situated in the Black Sea Region.

Importance of the Black Sea Electric Power Ring project consists of a number of components, as below:

1) The Black Sea Electric Power Ring enables state lacking energy producing resources gain a systematized, adjusted and institutionally formatted level of meeting their energetic needs within main parameters of general Black Sea energy market.

2) The project will bear an expanded nature both in geographical and energy-forming aspects. As regards the latter, it may be stated that the project in question will be also projected upon a broader sphere of energetic cooperation in the region. It will, in certain aspect, touch mutually related spheres of power energy supply and energy consumption - pipelines, building new power plants and upgrade of those existing, creating favorable climate for investments and transparency level increasing in such items as building pipelines and associated infrastructure, prices formation for resources being supplied granting suppliers and final consumers stability in determination of their policy in this sphere for forthcoming years; improvement of regional energy markets integration, cooperation in physical safety of relevant objects and strengthening of ecological component of energy production branch.

The Black Sea Electric Power Ring being such a great-scale project encompasses, first of all, all the BSECO member states will, obviously bear considerable geopolitical and geo-economical load. Attempts to link the EU via the Black Sea with the Caspian Sea resources lead to recognition of importance of Iranian resources and diverting transit routes for Russian gas.

Main objectives of involvement into the BSECO for Ukraine and partners may take following directions:

1) Priority system in relations with BSECO member states should be restructured to develop mutually acceptable ways to coordinate interests of member states with other international institutions and to elaborate appropriate mechanisms to overcome political discrepancies.

2) Varying levels of economical development among the BSECO member states is an unfavorable factor for integration processes in the Black Sea Region. Newer innovation base should be developed for regional economical development. Situation may be overcome by means of general 
reconstruction within the area, elimination of scientific and technological underdevelopment, especially by means of development telecommunications and computer networks, integration into worldwide information space. This purpose may be achieved by means of innovation development projects oriented to formation of manufacturing infrastructure of regional economical development taking into account advanced technologies and to proceed with developing and presenting for review and implementation projects of modernization of oil refineries according to latest standards, building newer production assets, particularly at the Black Sea coast for receiving oil and gas, carrying on joint scientific research with foreign corporations as to utilization of non-traditional energy sources, technological reconstruction of metallurgical plants and multilateral program of computer hardware manufacturing for various branches of economy within the BSECO.

3) Prospective direction may be represented by formation of regional safety system, especially by means of applying joint efforts to achieve stability in the region and gaining a leading role in settlement of existing conflicts. Existing inter-ethnical conflicts within geopolitical BSECO region substantially affects development of economical cooperation and threatens stability within the region. At the same time the BSECO may see it feasible to take upon themselves increased responsibility for creating situation of safety and stability within the region. With available mechanism enabling to hold international consultations at the top level and at the level of Foreign Ministries, the BSECO should keep under special surveillance and to include into agenda items concerning settlement of conflicts within the geopolitical area of the Black Sea. Common position should be developed regarding conflict situations and propose mediation attempts to parties in conflict in the settlement process. Since Ukraine has a rich experience in similar procedures, Ukraine may take a leading part in such processes within the BSECO and rise further questions as to formation of regional joint peace-making forces which may be gradually sent into conflict zones under appropriate UN Safety Council or the EUSCO mandates. Common naval forces (BLACKSEAFOR) may play a special role in supporting peace and stability within the region.

4) Taking into consideration substantial transit potential of the region with views of prospective intensive development of transport communications and energy transfer and appropriate infrastructure linking Europe and Asia, it is feasible for Ukrainian policy to focus already now upon bringing transport infrastructure in compliance with European standards. It is of utmost importance to prevent creation of new transport corridors and road routes evading Ukrainian territory. It is development of transport and communication network of the region that may contribute favorably to its integration into worldwide economical system and strengthen internal integration processes in the region. Ukraine, thus, might initiate development of targeted program to provide safety of strategic transport and energy routes and to involve all the regional and sub-regional aids and forces to achieve this aim. Such a program, among other key directions, might provide for monitoring safety status of communications lines, formation of specialized mobile units for their protection and terroristic actions prevention.

Trans-border cooperation is traditionally regarded as one of the most efficient tools of Ukrainian policy of European integration, especially regional generation and efficient partnership. By the way, Ukrainian administrative and territorial units are members of four European regions. Odessa Region is involved into activities of one of the most dynamic regions "The Lower Danube" for already 10 years. Statute of the latest European Region "The Black Sea" is expected to be approved this summer, with five Ukrainian regions striving to participate, including Odessa Region.

Creation of cooperation system and mechanism within the basin of the black Sea and participation of Ukrainian regions in such a partnership meets national interests of Ukraine provided it involves all the participants within the European regions' framework. "European Region" as a format of trans-national cooperation, i.e. cooperation between two, or more, administrative units of different European States is a definition applicable with EC. This term should not be mixed with "regions in Europe" or "dimensions of foreign policy" existing within the EU framework. 
European Region is not a supranational or supra-Governmental structure, but represents a format facilitating regional cooperation of its members. Decisions adopted by European Region don't possess mandatory status or legal acts status and concern only partners relation between members. They have status of recommendations only and take effect only after their approval, registration and notification of concerned parties.

The Black Sea Euroregion, alias BSER, is expected to become this summer another region involving Odessa Region. After the first Euroregion was established in Venice in February, 2006 (with accent to cooperation within the basin of semi-closed sea involving both EU member states and non-EU states) name as "Adriatic" the EC Congress of Local and Regional Authorities got an idea to establish similar formations near the Baltic Sea and the Black Sea. In their final declaration all the participants in conference (except Russian Federation) addressed the EC Congress of Local and Regional Authorities to assist in formation "Black Sea Euroregion" by the end of 2007 and applied to EC Ministers Committee to support the announced initiative.

\section{Conclusions}

1. Regional cooperation between the states situated at the Black Sea is grounded on multiple common interests. There are certain aspects where individual states attempt to use their potential and advantages to their sole benefit, however, being incapable to implement them successfully by themselves. At present the BSECO is a sole competent organization of regional scale possessing mechanism of regional cooperation development and regarded by most parties in concern about the Black Sea Region as potentially authoritative and the most efficient regional structure. The BSECO significance rises gradually, which is caused, to a certain extent, by the EU interest about it.

2. The EU involvement into processes within Extended Black Sea Region is caused by factors displaying interests and strategic plans of EU in the region in question. Furthermore, it is likely to expect increase in the EU involvement into projects, programs and processes in the region which is implicitly confirmed by issue of "The Black Sea Synergy" document and further review of EU concept to participate in regional integration processes and increasing cooperation with the BSECO. Growth of EU member states number, including Greece, Romania and Bulgaria situated at the coast of the Black Sea, is an important factor for deepening such tendencies. It gives reasons to expect development of the "Black Sea lobby" within the EU structures and implementation of projects and programs oriented to the Black Sea direction which so far cannot be regarded as successful, unlike Baltic, Southern and Mediterranean vectors.

3. Ukraine, as one of the major participants of regional cooperation between the Black Sea countries is directly interested in development of this region, strengthening of safety and democracy, deepening economical cooperation, guaranteeing human rights and freedom, etc. Extending cooperation with the EU and regional processes' integration into European are the most efficient way to achieve the above aims. Abovementioned facts demand insistently to review thoroughly both existing strategies of development of European and regional integration processes in the Extended Black Sea Region, and mechanisms by means of which common interests of associated states may be met and entire regional potential may be achieved. Steps should be selected to improve the BSECO status and attractiveness of regional cooperation for member states and neighboring states.

4. Ukrainian involvement and participation in the "Black Sea" euroregion may enable to solve more promptly problems existing within near border areas at a local level and to establish flexible economical structures. Applying a cluster model in trans-border cooperation may enable to increase competitiveness and investments prospects of regions adjacent to borders which are, normally, remote from active business centers and are typically depressed economically. Transborder cluster unites into a monolith integrated manufacturing complex corporations residents of a number of states around innovating corporation which generates modern technologies, newer knowledge, information, funding, and infrastructure. Cluster formation provides implementation 
of ventures projects on the basis of forecasted demands for innovation products, advanced technologies transfer improving economic safety level and producing social effect.

5. To the author's opinion, a strategy should be worked out to increase competitiveness of euroregional economy involving Ukraine on the basis of formation and development of innovative cluster structures. Once such attraction poles for resources are established in nearborder regions of Ukraine, they may minimize or neutralize threats and stimulate economical growth even on the background of global instability.

\section{References}

1. "Principles of National Security of Ukraine: Law of Ukraine, No. 964-IV, 19.06.2003» [Pro osnovy natsionalnoi bezpeky Ukrainy: Zakon Ukrainy, No. 964-IV, 19.06.2003], Vidomosti Verkhovnoi Rady, No. 39, p. 351 (ukr)

2. «On main directions of foreign policy of Ukraine: Resolution of the Verkhovna Rada of Ukraine, No. 3360-XII, 02.07.1993» [Pro osnovni napriamy zovnishnoi polityky Ukrainy: Postanova Verkhovnoi Rady Ukrainy, No. 3360-XII, 02.07.1993], Vidomosti Verkhovnoi Rady, No. 37, p. $379(u k r)$

3. "National Security Strategy of Ukraine: President Decree of Ukraine, No. 105/2007, 12.02.2007» [Stratehiia natsionalnoi bezpeky Ukrainy: Ukaz Prezydenta Ukrainy, No. 105/2007, 12.02.2007], available at: http://www.portal.rada.gov.ua (ukr)

4. "Prospects of cooperation between the EU and the Black Sea regional organizations»: Proceedings of International Conference, (Kyiv, April 27, 2007) [Perspektyvy spivrobitnytstva mizh JeS ta rehionalnymy orhanizatsiiamy Chornomorskoho rehionu: Materialy mizhnarodnoi konferentsii], National Institute of International Security Problems, Kyiv, 182 p. (ukr)

5. Geyets, V. M., Seminozhenko, V. P., Kvasnyuk, B. Ye. (2007), Strategic Challenges of the XXI century society and economy in Ukraine [Stratehichni vyklyky XXI stolittia suspilstvu ta ekonomitsi Ukrainy], Feniks, Kyiv, vol. 3, p. 244 (ukr)

6. Mikula, N. A. (2008), Strategy development and support the development of cross-border clusters. Ed. By Ye. I. Boyko [Stratehiia formuvannia ta pidtrymky rozvytku transkordonnykh klasteriv; za red. Ye. I. Boiko], Socio-economic problems of the modern period of Ukraine. Clusters and competitiveness of the border regions, Institute of Regional Research National Academy of Science of Ukraine, Lviv, issue 3 (71), pp. 129-141 (ukr)

7. Dolishniy, M. I., Belenkiy, P. Yu., Homelska, N. I. (2006), Strategic factors of global competition and mechanisms to ensure the competitiveness of regions; Competitiveness: Problems of Science and Practice: monograph [Stratehichni faktory hlobalnoi konkurentsii $i$ mekhanizmy zabezpechennia konkurentospromozhnosti rehioniv; Konkurentospromozhnist: problemy nauky $i$ praktyky: monohrafiia], INZHEK, Kharkiv, pp. 9-31 (ukr)

8. Lysenko, K. V. (2003), Organization of Black Sea Economic Cooperation in integration development of Ukraine Организация Черноморского экономического сорудничества в интеграџионном развитии Украины [Organizatsiya Chernomorskogo ekonomicheskogo sorudnichestva $v$ integratsionnom razvitii Ukrainy], Problems and prospects of cooperation development between the countries of South-Eastern Europe under the Black Sea Economic Cooperation and GUUAM, DonNU, Donetsk, pp. 455-464 (rus)

9. Makogon, Yu. V. (2004), Black Sea landmarks of European integration of Ukraine into the world economy [Chernomorskie orientiry evropeyskoy integratsii Ukrainy v mirovoe hozyaystvo], Problems and prospects of cooperation development between the countries of South-Eastern Europe under the Black Sea Economic Cooperation and GUUAM, SA «D. A. Tsenov», DonNU, Svishtov-Donetsk, pp. 22-38 (rus) 